\title{
Cruzando os mares: os grupos Opinião e Teatro Moderno de Lisboa - resistência e contestação político-cultural na década de 1960
}

\author{
Crossing the ocean: Opinião and Teatro Moderno \\ de Lisboa - resistance and political-cultural \\ contestation in the 1960s
}

Kátia Rodrigues Paranhos

\section{Cena I: arte e engajamento}

Teatro popular e teatro engajado são duas denominações que ganharam corpo por intermédio de um vivo debate que atravessou o final do século XIX e se consolidou no século XX. Seu ponto de convergência estava na tessitura das relações entre teatro e política ou mesmo entre teatro e propaganda. Para o crítico inglês Eric Bentley (1969), o teatro político se refere tanto ao texto teatral

Kátia Rodrigues Paranhos é doutora em História pela Universidade Estadual de Campinas/Unicamp, professora associada da UFU e editora de ArtCultura: Revista de História, Cultura e Arte (www.artcultura.inhis. ufu.br) (akparanhos@uol.com.br).

Artigo recebido em 26 de dezembro de 2011 e aprovado para publicação em 23 de março de 2012. 
como a quando, onde e como ele é representado. Por vezes condenada como escapista, outras vezes incensada como ferramenta de libertação revolucionária, a arte, de modo geral, continua sendo um tema candente tanto na academia como fora dela.

Aliás, não é demais relembrar que diferentes grupos teatrais, desde o final do século XIX, (re)colocam em cena movimentos a contrapelo ou, se se quiser, exercícios de experimentação, marcas de um outro tipo de teatralidade, de uma outra estética e - por que não dizer? - de uma outra forma de intervenção no campo social. Na Alemanha e na França, só para exemplificar, propostas como a do Freie Bühne (Cena Livre), de 1889, ou do Théatre du Peuple (Teatro do Povo), de 1885, pretendiam ir além do mero barateamento do custo do ingresso. Ao mesmo tempo, houve inúmeras iniciativas vinculadas às associações e aos clubes operários em distintos países da Europa. A nova dramaturgia apontava, como principal característica, a celebração do trabalhador como tema e intérprete, aliada à perspectiva do resgate, para o teatro, dos temas sociais.

Voltando a atenção para o teatro americano da primeira metade do século XX, podem-se recontar várias histórias. Basta retomar o movimento teatral dos trabalhadores americanos, atirados ao esquecimento pela tradição que concebeu a história e a estética oficiais do teatro. Grupos teatrais como o Artef (1925), Workers Drama League (1926), Workers Laboratory Theatre (1930) e Group Theatre (1931) não apenas mostravam suas ligações com os anarquistas, socialistas e comunistas - incluindo aí alguma aproximação entre intelectuais, artistas e militantes de esquerda -, como também registravam as influências das propostas do teatro político de Piscator. ${ }^{1}$

Ao saudar a presença do teatro engajado na década de 1960 nos Estados Unidos, Eric Bentley lembra que o fenômeno teatral por si só é subversivo:

(...) onde quer que 'duas ou três pessoas se reúnam', um golpe é desfechado contra as abstratas não-reuniões do público da TV, bem como contra as reuniões digestivas de comerciantes exaustos na Broadway. (...) A subversão, a rebelião, a revolução no teatro não são uma mera questão de programa, e muito menos podem ser definidas em termos de um gênero particular de peça (Bentley, 1969: 178).

Em artigo de 1968, Dias Gomes declara:

Toda arte é, portanto, política. A diferença é que, no teatro, esse ato é praticado diante do público. (...) o teatro é a única arte (...) que usa a criatura humana como meio de expressão. (...) Este caráter de 
ato político-social da representação teatral, ato que se realiza naquele momento e com a participação do público, não pode ser esquecido (Gomes, 1968: 10).

Por isso, no entendimento de Gomes, coube ao teatro um papel de destaque na luta contra a ditadura implantada no Brasil em 1964. Afinal, desde Anchieta - "nosso primeiro dramaturgo" (Gomes, 1968: 13) -, teatro e política estão umbilicalmente ligados à questão da função social da arte. A defesa do engajamento, portanto, parte do princípio de que os autores que falam sobre a realidade brasileira (sob diferentes óticas) são engajados. Isso significa dizer que o teatro é uma forma de conhecimento da sociedade. Assim, mesmo quem se autoproclama não engajado ou apolítico, na verdade, assume uma posição, também, política.

As experiências do teatro operário, do Arena, dos Centros Populares de Cultura (CPCs), do Oficina e do Opinião em busca do político e do popular carrearam um amplo movimento cultural que envolveu grupos, diretores, autores e elencos - conjunto que sofreu um violento revés com o golpe civil-militar e, em particular, após ser decretado o AI-5 em $1968 .{ }^{2}$ A partir de então, para numerosos grupos, fazer um teatro popular significava assumir uma posição de rebeldia frente ao teatro comercial - o teatrão - e ao regime político; e até se pode detectar algumas expressões para essa forma de agitação, como teatro independente e/ou teatro alternativo. ${ }^{3}$

No que se refere ao campo da cultura, em especial ao teatro no Brasil do pós-1964, interessa salientar que, enquanto a maioria dos artistas estava profissionalmente vinculada à indústria cultural, outros buscavam provisoriamente o exílio e alguns ainda tentavam uma resistência à modernização conservadora da sociedade, inclusive ao avanço da indústria cultural. Estes procuravam se articular com os chamados novos movimentos sociais que, aos poucos, se organizavam mesmo com a repressão (sobretudo em alguns sindicatos e comunidades de bairro), e muitas vezes em atividades associadas com setores de esquerda da Igreja Católica. Em Santo André, por exemplo, foi fundado em 1968 o Grupo de Teatro da Cidade (GTC). Com outros grupos teatrais montados na periferia paulistana (tais como Núcleo Expressão de Osasco, Teatro-Circo Alegria dos Pobres, Núcleo Independente, Teatro União e Olho Vivo, Grupo Ferramenta de Teatro e Grupo de Teatro Forja), o GTC constituiu o "teatro da militância” - na expressão de Silvana Garcia. Por sinal, no entender dessa autora, os traços que mais "aproximariam esses grupos entre si e dariam a tônica do movimento dos independentes" seriam: "produzir coletivamente; atuar fora do âmbito profissional; levar o teatro para o público da periferia; produzir um 
teatro popular; estabelecer um compromisso de solidariedade com o espectador e sua realidade". Esses aspectos não devem elidir a "sutileza das diferenças" entre os grupos que garante a especificidade de cada um e marca as "divergências entre si" (Garcia, 2004: 124).

Vários desses grupos, como o Teatro União e Olho Vivo, o Ferramenta e o Forja, vinculavam-se aos movimentos sociais de bairros, aos sindicatos e a comunidades de base, fundindo política e cultura na reorganização da sociedade civil sob a ditadura.

Em Portugal, no início dos anos 1960, a situação sob o regime ditatorial de Antônio Oliveira Salazar não era nada fácil. As tentativas de mudança do panorama cultural, vindas tanto do cinema como do teatro, encontraram fortes resistências. Nesse sentido, a constituição do Grupo Teatro Moderno de Lisboa, em 1961, surgiu no seguimento de companhias que buscaram, de algum modo, inovar em termos de repertório e de métodos de trabalho, tais como: Comediantes de Lisboa, de 1944, Companheiros do Pátio das Comédias, de 1948, Teatro do Povo, de 1936, e Teatro Nacional Popular, de 1957. Esse tipo de contestação a um teatro "esclerosado e divorciado da realidade portuguesa" também se fez entre os grupos amador e universitário, menos sujeitos à ação da censura, destacando-se, por exemplo, em Coimbra, o Círculo de Iniciação Teatral da Academia de Coimbra (CITAC) e o Teatro dos Estudantes da Universidade de Coimbra (TEUC) e, em Lisboa, os Cênicos de Direito e de Letras (ver Lívio, 2009: 30).

É interessante verificar, nesse período, a presença de companhias brasileiras circulando com seus espetáculos em terras portuguesas. Cabe referir

o grande impacto da vinda a Lisboa do TUCA [Teatro da Universidade Católica de São Paulo], que se apresentaria, em 1966, no Teatro Avenida, com essa tocante e interventiva Vida e morte Severina de João Cabral de Mello Neto, com música de um compositor que então se iniciava prometedoramente - Chico Buarque de Holanda (Lívio, 2009: 30).

Apesar do salazarismo, as teorias de Bertolt Brecht e Samuel Beckett ganhavam corpo por intermédio de alguns grupos de teatro. ${ }^{4} \mathrm{O}$ dramaturgo Luiz Francisco Rebello acentua:

(...) o ano de 68 foi o que poderíamos chamar um ano-charneira. Momento dum processo dialético em que a quantidade ganha nova qualidade. 
No quadro da contestação global da sociedade de consumo, as formas tradicionais do teatro teriam de ser, elas também, postas em causa.

Mas - e aqui está a novidade - este pôr em causa não incidia apenas sobre o teatro burguês, esse falso teatro, fácil e falso, (...) denunciado por Antonin Artaud há já mais de sessenta anos; visava também o teatro dito de vanguarda, que, nascido sob o signo do não conformismo, foi a pouco e pouco aceite, e depois recuperado pelos mesmos que a princípio o recusavam, (...) e por fim veio também a institucionalizar-se.

Então, de ruptura em ruptura, de explosão em explosão, levanta-se o problema de um teatro alternativo (...) (Rebello apud Fundação Calouste Gulbenkian, 1988: 26, grifos do autor).

\section{Cena II: quem tem Opinião?}

No cenário Brasil pós-1964, segmentos importantes do teatro se destacaram ao manter uma posição de luta contra o regime. Na época, o grupo de artistas que esteve ligado ao Centro Popular de Cultura (CPC) da União Nacional dos Estudantes (UNE) se reuniu com o intuito de criar um foco de resistência e protesto contra aquela situação. Foi então produzido o espetáculo musical Opinião, com Zé Kéti, João do Vale e Nara Leão, cabendo a direção a Augusto Boal. O espetáculo, apresentado no Rio de Janeiro em 11 de dezembro de 1964, no Teatro Super Shopping Center, marcou o nascimento do grupo e do espaço teatral que veio a se chamar Opinião. Os integrantes do núcleo permanente eram Oduvaldo Vianna Filho (o Vianninha), Paulo Pontes, Armando Costa, João das Neves, Ferreira Gullar, Thereza Aragão, Denoy de Oliveira e Pichin Plá.

O show foi organizado no famoso Zicartola - restaurante do sambista e compositor Cartola e de sua companheira Zica-, onde ocorriam reuniões de músicos, artistas, estudantes e intelectuais (ver Garcia, 2008 e Castro, 2004). Foi esse o ambiente catalisador da união de interesses de experientes dramaturgos e músicos, com diferentes estilos e atuações no campo cultural, que resultou num roteiro inédito: um espetáculo musical que continha testemunhos, música popular, participação do público, apresentação de dados e referências históricas, enfim, um mosaico de "canções funcionais" (Hobsbawm, 1991: 52) e de tradições culturais. Tanto o enredo quanto o elenco eram notadamente heterogêneos e talvez seja esse $o$ motivo pelo qual o Opinião tenha começado sua trajetória com sucesso. $\mathrm{O}$ grupo privilegiou, desde a estreia, a forma do teatro de revista, numa mescla de apropriações e ressignificações do "popular" e do "nacional”, abrindo igualmente espaço para apresentações com compositores de escolas de samba cariocas. 
João das Neves, que dirigiu o Opinião por 16 anos, enfatiza:

$\mathrm{O}($...) trabalho era fundamentalmente político e, assim, pesquisar formas nos interessava - e interessa - muito. (...) A busca em arte não é apenas estética - ela é estética e ética ao mesmo tempo. Eu coloco no que faço tudo o que eu sou, tudo o que penso do mundo, tudo o que imagino da possibilidade de transformar o mundo, de transformar as pessoas. Acredito na possibilidade da arte para transformar (Neves apud Kühner e Rocha, 2001: 58).

Podemos afirmar que o espetáculo não só focalizava como mistificava "novos lugares da memória: o morro (favela + miséria + periferia dos grandes centros urbanos industrializados) e o sertão (populações famintas, (...) o messianismo religioso (...) e o coronelismo)" (Contier, 1998: 20). Por meio da música, as interpretações e discussões a respeito dessas realidades fluíam no espetáculo, alternando-se com os depoimentos dos atores que compartilhavam, fora do palco, as mesmas dificuldades cantadas por eles, como nos casos de João do Vale (nordestino retirante) e Zé Kéti (morador de uma favela carioca). Já Nara Leão - conhecida como a musa da bossa nova que personalizava a classe média - assumia uma postura de engajamento e se posicionava de forma ativa e questionadora da realidade brasileira.

Esse movimento de aproximação das diferenças num palco de teatro foi conduzido por uma tendência ainda de caráter cepecista, uma vez que nos CPCs o principal lema era portar-se como transmissor de uma mentalidade revolucionária para o povo e assim atingir a tão utópica revolução social. ${ }^{5}$ Não poderia ser diferente, pois os dramaturgos do Opinião, como Vianninha e o poeta Ferreira Gullar, eram membros ativos dos CPCs e utilizavam suas peças, inclusive o musical Opinião, como meio de "fazer emergir" na plateia "valores novos" e uma "capacidade mais rica" de sentir a "realidade" (Kühner e Rocha, 2001: 54-55) 6 no intuito de estabelecer uma identificação entre os atores e o público. Segundo Heloísa Buarque de Hollanda e Marcos Gonçalves, "encenava-se um pouco da ilusão que restara do projeto político-cultural pré-64 e que a realidade não parecia disposta a permitir: a aliança do povo com o intelectual, o sonho da revolução nacional e popular" (Hollanda e Gonçalves, 1995: 23-24).

Mas não só a junção de música e teatro tornou o Opinião uma referência. Sua relevância histórica se evidenciou, entre muitos motivos, graças ao momento no qual foi gerado: a estreia do show ocorreu quando o golpe civil-militar ainda não completara um ano de vida e é tida como a primeira grande expressão artística de protesto contra o regime. Também chama atenção a configuração geral 
do espetáculo, que, num teatro em forma de arena, não dispunha de cenários, mas somente de um tablado onde três "atores" encarnavam situações corriqueiras daquele período, como a perseguição aos comunistas, a trágica vida dos nordestinos e a batalha pela ascensão social dos que viviam nas favelas cariocas, tudo isso, acrescente-se, regado a música que visava a alfinetar a consciência do público. O repertório, embora fosse assinado por compositores de estilos diversificados, percorria uma linha homogênea de contextos regionais, concedendo-se amplo destaque a gêneros musicais como o baião e o samba. As canções cantadas por sinal, várias delas marcaram os anos 1960 a ponto de frequentarem inclusive a parada de sucesso - exprimiam uma fala alternativa e ilustrativa no musical. Em "Borandá", de Edu Lobo, Nara Leão fazia ressoar, com sua voz melancólica, a tristeza dos retirantes que, impelidos pela seca, eram obrigados a abandonar a zona rural nordestina. Já em "Carcará", a composição mais emblemática do negro maranhense João do Vale, a mesma intérprete desfiava a história dessa ave sertaneja, apelando para metáforas sobre sua valentia e coragem; nessa canção era possível perceber a relação que se estabelecia entre o carcará e o governo militar, que investia com toda fúria contra os que a ele se opunham.

Incluir o(s) marginalizado(s) na cena teatral brasileira não foi um mérito exclusivo do show. Basta lembrar de Eles não usam black-tie de Gianfrancesco Guarnieri (ver Costa, 1996). Contudo, o formato musical e o roteiro não cronológico diferenciavam o show pela aproximação que esses elementos propiciavam entre palco e plateia. Como decorrência de toda a sua concepção, o show Opinião se calcava no pressuposto de que a representação da realidade se alinha com a perspectiva de "teatro verdade" e implica a criação de um ambiente de comunhão e igualdade entre todas as partes envolvidas no espetáculo, sobretudo o público, como se todos tivessem um denominador comum: estariam irmanados por pertencerem, de maneira inescapável, à mesma realidade (ver Costa et al., 1965). ${ }^{7}$

Vejamos o comentário de Augusto Boal:

Eu queria que escutassem não apenas a música, mas a idéia que se vestia de música! Opinião não seria um show a mais. Seria o primeiro show de uma nova fase. Show contra a ditadura, show-teatro. Grito, explosão. Protesto. Música só não bastava. Música ideia, combate, eu buscava: música corpo, cabeça, coração! Falando do momento, instante! (Boal, 2000: 226).

Por intermédio desse acontecimento cênico se visualiza um leque de representações. $\mathrm{O}$ teatro, portanto, passa a se caracterizar não somente como meio 
de encenação/interpretação, mas também como divulgador de lugares e sentidos político-culturais.

O show e o grupo Opinião podem ser vistos como exemplos do teatro engajado. Por isso mesmo, representam objetos de interessantes investigações históricas por formular uma voz de protesto inicial, ainda em 1964, configurando-se "como um protesto suprindo uma falta de algo: a possibilidade de dizer. Um protesto, sim, ainda que sob a forma espontânea, simples e improvisada de uma opinião" (Kühner e Rocha, 2001: 46). Nessa perspectiva, os grupos de teatro integram um conjunto significativo de documentos inseridos em certo contexto sócio-histórico e se constituem como fragmentos de um período e uma forma interpretativa do social.

Cabe registrar que vários autores preocupados com a situação pós-golpe abrem discussões acerca da importância do teatro, dos dramaturgos e atores que foram personagens ativos desse período de repressão. Entre eles podemos citar Maria Helena Kühner e Helena Rocha, que trabalham a formação do Grupo de Teatro Opinião (e o show inaugural) como referência de postura política no início do governo militar. $\mathrm{Na}$ leitura da análise por elas desenvolvida é possível vislumbrar, na constituição do Opinião, uma expressão de urgência de mudança almejada por um grupo que muitos qualificavam de "idealistas, utópicos, românticos, ingênuos, lou$\cos (. .$.$) que viveram a geração da utopia" (Kühner e Rocha, 2001: 34-35).$

Por sinal, vale a pena retomar alguns trechos de duas músicas do espetáculo, que empolgavam de maneira especial a plateia que superlotava o teatro naquelas noites sombrias. Na primeira, "Opinião", Zé Kéti cantava: "Podem me prender/Podem me bater/Podem até deixar-me sem comer/Que eu não mudo de opinião". Na segunda, "Carcará”, pela voz de Nara Leão, João do Vale narrava as aventuras de um pássaro voraz do sertão, que não morre porque, com seu bico volteado que nem gavião, "pega, mata e come" (Costa et al., 1965: 41 e 62). ${ }^{8}$

Opinião foi a primeira aula dada ao público sobre como reaprender a ler certas obras de arte - ensinamento extremamente útil nos anos (de censura) que se seguiram. O clima (...) era de catarse e sublimação. Vivia-se a sensação de uma vitória que tinha sido impossível lá fora (Kühner e Rocha, 2001: 72).

O sentimento de transformação política está presente em todo o corpo da peça. Suas origens musicais, o passado dos integrantes no cenário de oposição e intervenção política, bem como as particularidades dos atores estreantes, tornam-se intrigantes peças de um complexo quebra-cabeças que faz desse espetáculo uma importante referência na trajetória engajada do teatro brasileiro. Para Dias Gomes, coube ao teatro um papel de destaque na luta contra a ditadura im- 
plantada no Brasil em 1964: "a platéia que ia assistir ao show Opinião, por exemplo, saía com a sensação de ter 'participado' de um ato contra o governo" (Gomes, 1968: 15).

Cabe ainda destacar a riqueza de ideias, a fórmula da colagem, a participação do público, a reafirmação da resistência, a valorização das práticas culturais populares, a cumplicidade palco-plateia, a temática ligada à realidade brasileira, a concepção multifacetada de gêneros musicais. Se, como aponta Edélcio Mostaço, de um lado a encenação exercitava "uma comunicação de circuito fechado: palco e plateia irmanados na mesma fé" (Mostaço, 1982: 61), de outro, na mesma medida, para Marcos Napolitano, representava "a ampliação e a massificação do público, bases fundamentais para entender a entrada dos produtores culturais de esquerda na indústria cultural" (Napolitano, 2001: 75).

É importante salientar que o grupo Opinião focalizava suas ações no teatro de protesto, de resistência, e também se caracterizava por ser um centro de estudos e de difusão da dramaturgia nacional e popular. Afinado com essas propostas artísticas e ideológicas, o diretor João das Neves privilegiava a montagem de textos, tanto nacionais quanto estrangeiros, que servissem de enfoque para a situação política do Brasil nos anos da ditadura, tais como: $A$ saída, onde fica a saída?, em 1967, de Armando Costa, Antônio Carlos Fontoura e Ferreira Gullar; Fornada de um imbecil até o entendimento, em 1968, de Plínio Marcos; Antígona, em 1969, de Sófocles, numa tradução de Ferreira Gullar; $A$ ponte sobre o pântano, em 1971, de Aldomar Conrado; O último carro, em 1976, Mural mulher, em 1979, e Café da manhã, em 1980, de João das Neves. ${ }^{9}$

Outra referência básica que merece destaque é a utilização da dramaturgia e dos métodos propostos por Bertolt Brecht. Recorto um trecho que me parece bastante sugestivo:

Quero falar sobre o que Brecht representa para nós. Participei, nos idos de 63/64, do Centro Popular de Cultura (CPC) e depois fui um dos fundadores do Grupo Opinião do Rio de Janeiro. Nas preocupações iniciais, no ideário do Centro Popular de Cultura, estava a luta pela transformação da sociedade, que acreditávamos que pudesse ser realizada, inclusive através do teatro, usando-o como instrumento dessa transformação. A revelação de Brecht para nós, as discussões sobre Brecht naqueles momentos, foram extremamente ricas, porque nos revelaram que o teatro político tinha outros caminhos que não apenas o "agit-prop", que não apenas a agitação e propaganda. Brecht nos mostrou que o teatro não excluía a possibilidade do aprofundamento, quer nos sentimentos, quer no mecanismo da existência do homem em sociedade. Ele não precisava ser tão imediato para ter sua contundência, sua 
eficácia política comprovada. Essa primeira constatação veio através do estudo de Brecht. Embora estivéssemos longe de aplicar as teorias de Brecht, diretamente, em nosso trabalho, seu estudo foi para nós de extrema importância, para que pudéssemos fazer uma avaliação crítica do trabalho que estávamos realizando nas ruas, nos sindicatos: o teatro de "agit-prop" que nós fazíamos no CPC e seus possíveis desdobramentos. Depois do golpe de 1964, um grupo de pessoas que saíra do CPC veio a formar o grupo Opinião e este grupo aprofundou um tipo de dramaturgia e de encenação que, se não tinha Brecht como ponto de partida, deve, no entanto, à sua reflexão muito da qualidade alcançada (...) Na história de um grupo como o Opinião e na história de grupos como o Arena e o Oficina, a passagem por Brecht, o conhecimento dele, a leitura ou a realização de suas peças, a discussão de suas teorias, o entrar em contato com seu humor, com um novo tipo de abordagem teatral, com uma nova relação ator-espectador, são de suma importância (Neves apud Bader, 1987: 242 e 244).

Como já assinalado anteriormente, em 1976 o Opinião levou à cena carioca o texto O último carro, de João das Neves, escrito em 1967 e vencedor do Prêmio de Montagem do Seminário Nacional de Dramaturgia do Serviço Nacional de Teatro. Por sinal, vale mencionar que por conta desse trabalho João das Neves recebeu o Prêmio Molière de melhor direção e o Prêmio Brasília de melhor autor, naquele ano, e o Prêmio Mambembe de melhor diretor em 1977.

Numa fantástica ambientação cenográfica de Germano Blum, que dá ao espectador a exata sensação de estar viajando num trem de subúrbio, desenrola-se uma série de pequenos mas terríveis dramas cotidianos vividos pelos habitantes da periferia que dependem desse meio de transporte. (...) João das Neves, ao mostrar a dura realidade desse submundo e ao cercá-la de generoso calor humano, criou o equivalente brasileiro de "Ralé", a obra-prima de Gorki (Michalski, 1985: 67).

"O último carro ou As 14 estações é um texto em que o povo brasileiro é agente e paciente, autor e intérprete de si mesmo" (Neves, 1976: 5). E João das Neves acrescenta:

Seu universo é o universo dos subúrbios cariocas, onde vivem mais de $65 \%$ da população útil do Rio de Janeiro. É o universo dos que precisam se utilizar diariamente dos trens suburbanos. Neles per- 
dem $1 / 3$ dos seus dias, $1 / 3$ das suas vidas. É o universo dos "emparedados" pelos vagões da Central ou Leopoldina ou qualquer via férrea por este Brasil afora. É um universo trágico, regido pelos deuses cegos de um Olimpo sem grandeza, num mundo que não produz mais herói porque o heroísmo está encravado na luta cotidiana pela sobrevivência de toda a população de uma cidade, de um país, de um mundo (Neves, 1976: 5). ${ }^{10}$

\section{Cena 3: TML: um teatro de combate}

Cruzando os mares, pretendo ressaltar outra experiência de produção e pesquisa: a da Companhia Teatro Moderno de Lisboa (TML), que para muitos intérpretes "rompeu a ordem estabelecida da vida teatral na década de 1960 e se afirmou como o grande movimento de uma geração" (Lourenço apud Lívio, 2009: 201). Durou apenas quatro anos, de 1961 a 1965. Nesse período o grupo apresentou textos teatrais de Carlos Muniz, Dostoievsky, Miguel Mihura, John Steinbeck, Luiz Francisco Rebello, William Shakespeare e José Carlos Pires. Esses leitores teatreiros compuseram e recompuseram diferentes universos de acordo com suas intenções e seus desejos. Deram, ao "passado e presente em um" (Brecht, 2000: 233), o sinônimo de aliar a leitura (com significados novos) de textos, recheados de crítica social em determinado contexto, à representação operária de um grupo de atores portugueses. Como lembra Fredric Jameson - a propósito do filme Notícias da Antiguidade ideológica, de Alexander Kluge -, o que importa é a "miscelânea" ou a "montagem de sentimentos"(Jameson, 2010: 69).

As questões políticas e estéticas contidas nas peças eram atualizadas pelo debate entre o grupo de teatro e a plateia - tarefa bem difícil num período em que a contestação político-cultural à ditadura do "Estado Novo" se tornava mais forte e constante e em que a repressão da censura oficial, sempre vigilante para com as manifestações artísticas heterodoxas, fazia-se sentir de uma forma asfixiante. Lembrando aqui a idéia de Natalie Davis, esses homens e mulheres eram "usuários e intérpretes ativos" dos textos impressos que liam e ouviam e aos quais também ajudavam "a dar forma" (Davis, 1990: 184).

Cabe registrar, mais uma vez, que a década de 1960 traria novos e ricos rumos para o teatro, desde o Living Theater, com seus rituais e hapennings, às teorias do polaco Jerzy Grotowsky, autor de uma corrente mais despojada, dando larga importância à expressão do corpo cênico, o chamado "teatro pobre" e passando pelos young angry men da Inglaterra até Peter Brook e sua noção peculiar do espaço teatral e de uma nova relação palco/público. Esses movimentos, observados em parte pelo mundo ocidental, correspondiam a um mútuo anseio de criadores, artistas e públicos jovens que não se reconheciam mais no teatro tradicio- 
nal, questionando-o e buscando outras e mais desafiantes alternativas, transformando, amiúde, o teatro num laboratório, permeável a diferentes experiências e à fusão com elementos cênicos de outras culturas. ${ }^{11}$

Reclamava-se um novo teatro, exigindo uma relação distinta entre o texto, o público e os criadores (atores e encenadores), algo que, nos EUA, estava patente na ação de Elia Kazan, primeiro no Group Theatre (1931) e mais tarde (1961) no Lincoln Center, com a criação do Lincoln Center Repertory Theatre, que tanto iriam influenciar as jovens gerações - caso de Clifford Odets, Arthur Miller e Edward Albee. Por sinal, as bases programáticas do Lincoln Center Repertory Theatre estavam muito próximas das definidas, no mesmo ano, pelo Teatro Moderno de Lisboa:

Formamos um grupo de seres humanos que quer fazer arte e não dinheiro... Será um grupo de teatro comprometido... Defenderá a criação contra a esterilidade, a liberdade contra a escravidão, a investigação contra o dogma, o impulso contra a repressão... A vida contra a morte (apud Lívio, 2009: 28). ${ }^{\text {I2 }}$

O TML colaborou, portanto, para a instituição de um campo de circulação e de trocas culturais. Os atores tentaram, de algum modo, inovar em termos de repertório e de métodos de trabalho, fugindo da "comédia ligeira" e/ou do "teatro dramático", "divorciado" da "realidade portuguesa" (Lourenço apud Lívio, 2009: 202). Atores de prestígio como Carmen Dolores, Rogério Paulo, Armando Cortez, Ruy de Carvalho e Fernando Gusmão se juntaram para formar uma companhia fora dos circuitos comerciais e com objetivos culturais completamente diferentes daqueles do teatro que então se fazia.

A criação do Teatro Moderno de Lisboa foi um dos momentos mais belos e exultantes da minha vida. Fui um dos seus fundadores mais entusiastas e empenhados. Estava tão saturado de fazer teatro comercial, cuja importância, aliás, reconheço, mas, tanto eu como os restantes companheiros desta autêntica aventura, queríamos voltar-nos agora para um teatro de grandes textos por nós escolhidos, moderno como o seu nome indicava, e que, por tal, nos desse um enorme gozo interpretar (Carvalho apud Lívio, 2009: 178).

Na declaração de intenções do TML constava, para além da revelação de novos dramaturgos nacionais e estrangeiros, uma abordagem diferente dos clássicos. De acordo com as normas de funcionamento, cada integrante ia propondo 
peças que estivessem dentro dos parâmetros do Manifesto da companhia, até porque teria que enviar para o exame prévio da censura um lote grande de originais, sabendo-se antecipadamente que só alguns seriam aprovados. Assim, por exemplo, foi Tomás de Macedo que deu a conhecer, e sugeriu ao grupo, a peça $O$ tinteiro, do dramaturgo espanhol Carlos Muñiz (ver Lívio, 2009: 45-47).

Desse modo, em 1961, no Cinema Império, local de funcionamento das matinês, ${ }^{13}$ a recém-formada companhia portuguesa estreava $O$ tinteiro - uma peça sobre a liberdade no tempo da ditadura. O enredo focaliza a ação de três funcionários obedientes a um patrão injusto e prepotente que atormenta, em especial, a existência do personagem principal, o tinteiro Crock, esmagado num escritório pelo absurdo das leis que proibiam a alegria, o amor, uma simples flor numa jarra. "Será possível trabalhar e cheirar as flores da primavera? (...) Poderemos gostar de poesia, mesmo se são os números de uma qualquer contabilidade que nos preenchem os dias à secretária?". São algumas perguntas que Crock levanta num ambiente em que a palavra de ordem é "obedecer sem questionar" (Rebello, 1977: 42).

Antônio Costa Ferreira que, segundo ele próprio confessa, devido ao seu físico, foi frequentemente chamado para papéis odiosos, como o Frank de O tinteiro, afirma ter sido com muito gozo que o "vestiu" em cena:

Tratava-se de um miserável chefe de repartição, de casaco coçado com manguitos de alpaca e jaquetão preto para os momentos solenes, que tortura friamente os seus subordinados. Com a indumentária de jaquetão preto e calças de fantasia, então usada nas tardes solenes do Estado Novo e pelos chefes de mesa do Gambrinus, eu quis dar a mediocridade do tirano fascista. Com o bigode à Hitler, a ambição do poder despótico e universal e com a voz sibilante, a sugestão da voz de Salazar que, quando pela rádio chamava os portugueses, nos dava a certeza de ficarmos com um pouco menos de esperança. Aliás, a encenação claríssima de Rogério Pulo punha Frank, não como beneficiário máximo da exploração trágica, mas como funcionário de um poder abstrato, de fraque e óculos escuros, que não podia deixar de ser o capitalismo. O ódio a Salazar deu autenticidade a este papel, como o Método ensina (Ferreira apud Lívio, 2009: 65).

Para o ator Armando Caldas,

o Tinteiro foi uma autêntica bomba, não só em Lisboa mas em Portugal (percorremos quase todo o país). Basta consultar os jornais da época. $\mathrm{O}$ êxito deste espetáculo teve, como consequência, assus- 
tar o poder político de então, pois notou-se, a partir daí, uma implacabilidade da censura para as peças que enviávamos para sua aprovação. $\mathrm{O}$ que incomodou também muito os governantes foi o facto de termos criado o "Núcleo de Amigos do TML", onde se inscreveram milhares de pessoas identificadas com a nossa programação e que, muitas vezes, organizavam excursões para ver os nossos espetáculos e promoviam a realização de outros, em várias localidades onde, frequentemente, se faziam debates sobre o que acabavam de ver. (...) como alguém disse, “o Teatro Moderno de Lisboa foi uma grande pedrada no charco do marasmo cultural de Portugal" (Caldas apud Lívio, 2009: 177).

Importa lembrar que em 1961 começara a guerra em Angola e que foi preciso esperar mais de 15 anos para surgirem peças portuguesas sobre esse trágico acontecimento. Muitos dramaturgos portugueses contemporâneos escreviam, sabendo que muito dificilmente suas peças seriam representadas, pois qualquer texto que tivesse alguma preocupação social ou algum motivo que visasse à liberdade individual era logo banido pela censura. José Cardoso Pires definiu a década de 1960 como "o consulado de terror de Paulo Rodrigues", ministro-adjunto de Salazar que se vangloriava, quando este morreu, de ter sido "uma lapiseira nas mãos de Sua Excelência". "Uma lapiseira que não se limitava a escrever o que o dono lhe ditava, mas que riscava e cortava o que os outros escreviam..." (Rebello apud Lívio, 2009: 18).

Até para se pôr uma fotografia à porta do teatro com uma cena da peça, fosse que cena fosse, era necessário submetê-la à Comissão dos Espetáculos, um departamento ligado à censura, e aguardar o carimbo da respectiva autorização. Também não se podia fazer teatro num lugar que não fosse, a princípio, adequado para isso. À Direção Geral dos Espetáculos cabia decidir quem podia ter espaço para representar. Nessas condições, qualquer iniciativa nova morria à nascença ou tinha de ser acolhida pelos empresários do chamado teatro comercial e desvirtuada no seu conteúdo.

No entanto, mesmo com tantos entraves, o TML formaria atores, públicos, revelaria novos valores da dramaturgia nacional (como Cardoso Pires) e estrangeira (Carlos Muniz e Miguel Mihura), novos encenadores (Rogério Paulo, Fernando Gusmão, Costa Ferreira, Armando Cortez, Paulo Renato), artistas plásticos (Octávio Clérigo, Luís Jardim) e ainda músicos de cena (Carlos Paredes, Antônio Vitorino de Almeida), de tal forma que, para o crítico de teatro Tito Lívio,

se pode dizer, sem exagero, que, em pleno salazarismo, a criação do Teatro Moderno de Lisboa foi uma espécie de "primavera" 
teatral, efêmera, mas marcante, já que acabaria mais cedo do que a vontade dos seus fundadores pretenderia, devido a uma série de obstáculos com que foram deparando ao longo do seu percurso (Lívio, 2009: 64).

Para Tito Lívio, a primavera teatral do TML pode ser organizada em três temporadas, levando em consideração a saída e/ou entrada de atores/“sócios": a primeira, de 1961 a 1962, com a encenação de O tinteiro e os Humilhados e ofendidos, de Dostoievsky e André Charpak; a segunda, de 1962 a 1963, com Os três chapéus altos, de Miguel Mihura, Ratos e homens, de John Steinbeck e George C. Kaufman, Não andes nessa figura, de Armando Cortez, O dia seguinte, de Luiz Francisco Rebello, $O$ pária, de Strindberg, e O professor Taranne, de Adamov; a terceira, de 1964 a 1965, com Dente por dente, de W. Shakespeare, eOrender dos heróis, de José Cardoso Pires (ver Lívio, 2009: 61-112).

Devido à sua ação, aos seus princípios fundamentais e práticas, o TML lançaria as sementes do movimento dos grupos de teatro independentes, iniciando o caminho de um teatro de intervenção que estes, mais tarde, se encarregaram de continuar. Nesse sentido, é interessante registrar que na década de 1960 os teatreiros brasileiros e portugueses leram e representaram de acordo com seu repertório sociocultural. Esse processo complexo se ampliava e se fortalecia com as discussões e os debates promovidos após as apresentações dos grupos. Era uma oportunidade a mais para trocar ideias sobre os textos encenados. Por sinal, ao se referir aos diferentes gêneros literários, Benoît Denis salienta que o teatro é um "lugar" importante do engajamento, pois, por intermédio da representação, "as relações entre o autor e o público se estabelecem como num tempo real, num tipo de imediatidade de troca, um pouco ao modo pelo qual um orador galvaniza a sua audiência ou a engaja na causa que defende" (Denis, 2002: 83).

Desse modo, os grupos de teatro, no Brasil e em Portugal, que combatiam tanto a ditadura como a censura imposta, atuavam em diferentes circuitos culturais. Fazer teatro engajado naquele período era buscar outros lugares de encenação, assim como outros olhares sobre os anos de chumbo. Várias dessas companhias uniam arte e rebeldia política.

Iná Camargo Costa, na orelha do livro Atuação crítica, adverte que mesmo em "tempos de total colonização da sensibilidade e do imaginário pela indústria cultural, desafios práticos e teóricos (são) postos desde sempre aos que se dispõem a fazer teatro ou qualquer modalidade de arte consequente no Brasil" (Costa apud Carvalho, 2009). Felizmente, apesar dos tempos modernos e das dificuldades advindas deles, as experiências teatrais na contramão do pensamento dominante continuam em pauta e na ordem do dia com incrível tena- 
cidade. Fazer teatro em meio às pressões comerciais é, sem dúvida, uma forma de provocação, de insubordinação ao mercado das "paradas de sucesso", da qual ainda se valem tanto o Teatro União e Olho Vivo (SP), o Engenho Teatral (SP), o Ói Nóis Aqui Traveiz (RS), o Tá na Rua (RJ) e o Galpão (MG). Sem falar, é claro, dos grupos portugueses, como o Comuna - Teatro Pesquisa, o Teatro da Cornucópia, O Bando, a Casa da Comédia, A Barraca, o Centro Cultural de Évora e a Seiva Trupe. ${ }^{14}$

Lembrando Crock, de $O$ tinteiro, "no mundo ainda há primavera" (Rebello, 1977: 43). A despeito das dificuldades cotidianas, ainda podemos respirar outros ares. Por isso mesmo, parafraseando Bertolt Brecht, apesar de tudo, mesmo quando somos derrotados, ainda temos a alternativa da lucidez. Dito de outra maneira, apesar do capitalismo selvagem - perdoem-me a redundância -, o que importa é continuar lutando para entender o que se passa. Farão ainda sentido estas palavras? Desce o pano.

\section{Notas}

1. Ver, entre outros, Samuel, Maccoll e Cosgrove, 1985, e Costa, 2001.

2. Sobre o golpe civil militar e seus desdobramentos, ver Toledo, 1997, e Reis, 2000 .

3. O termo independente origina-se de países da Europa e da América Latina, onde a organização teatral se dá em moldes diferentes dos grupos ligados ao poder estatal e/ou empresarial. Ver Dosio, 2003.

4. Sobre grupos de teatro, dramaturgia e censura política em Portugal, ver, entre outros, Fundação Calouste Gulbenkian, 1988, Santos, 2001, e Werneck e Brilhante (orgs.), 2009.

5. Sobre a noção de "povo" para os integrantes do CPC, ver Mostaço, 1982.

6. Sobre a experiência teatral do CPC no Rio de Janeiro, ver Neves, 1987.
7. Vale conferir uma visão crítica do show Opinião em Tinhorão, 1997:72-87.

8. Ver o CD Show Opinião, 1994.

9. Sobre os outros espetáculos do Opinião na década de 1970, ver Kühner e Rocha, 2001.

10. Ver também Neves, 1981.

11. Ver, entre outros, Garcia e Guinsburg, 2002:131-154.

12. Sobre o teatro americano e o Teatro Moderno de Lisboa ver, entre outros, Gould, 1968, Downer (org.), 1969, Rebello, 1977 e Wilcox, 1971.

13. O empresário José Gil, proprietário do Cinema Império, uma das salas mais prestigiadas de Lisboa, cedeu o espaço para o TML encenar suas peças nos tempos livres, ou seja, nas segundas 
matinês, às 18:30h nas segundas, terças, quintas e sextas-feiras e às $11: 30 \mathrm{~h}$ nos domingos. O Império, por sinal, era considerado uma "catedral da celebração cinematográfica, teatral e musical". Esse lugar da "contracultura" se transformou

\section{Referências bibliográficas}

BADER, Wolfang (org.). Brecht no Brasil: experiências e influências. Rio de Janeiro: Paz e Terra, 1987.

BENTLEY, Eric. O teatro engajado. Rio de Janeiro: Zahar Editores, 1969.

BOAL, Augusto. Hamlet e o filho do padeiro. Rio de Janeiro: Record, 2000.

BORGES, Gabriela (org.). Nas margens: ensaios sobre teatro, cinema e meios digitais. Lisboa: Gradiva, 2010.

BRECHT, Bertolt. Poemas 1913-1956. $5^{\mathrm{a}} \mathrm{ed}$. São Paulo: Ed. 34, 2000.

CARVALHO, Sérgio de et al. Atuação crítica: entrevistas da Vintém e outras conversas. São Paulo: Expressão Popular, 2009.

CASTRO, Maurício Barros de. Zicartola: política e samba na casa de Cartola e Dona Zica. Rio de Janeiro: Relume Dumará/Prefeitura, 2004.

CONTIER, Arnaldo Daraya. Edu Lobo e Carlos Lyra: o nacional e o popular na canção de protesto (os anos 60). Revista Brasileira de História, v. 18, n. 35, São Paulo, Anpuh, 1998, p. 13-52.

COPFERMANN, Émile. O teatro popular por quê? Porto: Portucalense Editora, 1971.

COSTA, Armando et al. Opinião: texto completo do show. Rio de Janeiro: Edições do Val, 1965. recentemente na sede da Igreja Universal do Reino de Deus. Ver Lívio, 2009: 39-40.

14. Ver, entre outros, Werneck e Brilhante (orgs)., 2009, e Borges (org.), 2010.

COSTA, Iná Camargo. A hora do teatro épico. Rio de Janeiro: Graal, 1996.

. Panorama do Rio Vermelho: ensaios sobre o teatro americano. São Paulo: Nankin Editorial, 2001.

DAVIS, Natalie Zemon. Culturas do povo. Rio de Janeiro: Paz e Terra, 1990.

DENIS, Benoit. Literatura e engajamento: de Pascal a Sartre. Bauru: Edusc, 2002.

DOSIO, Célia. El Payró: cincuenta anos de teatro independente. Buenos Aires: Emecé, 2003.

DOWNER, Alan S. (org.). O teatro norteamericano de hoje. São Paulo: Cultrix, 1969.

FUNDAÇÃO CALOUSTE GULBENKIAN. $O$ texto e o acto: 32 anos de teatro (1968-2000). Lisboa: Fundação Calouste Gulbenkian, 1988.

GARCIA, Silvana. Teatro da militância: a intenção do popular no engajamento político. $2^{\mathrm{a}}$. ed. São Paulo: Perspectiva, 2004.

e GUINSBURG, J. De Büchner a Bread \& Puppet: sendas do teatro político moderno. In: SILVA, Armando Sérgio da (org.).F. Guinsburg: diálogos sobre teatro. $2^{\mathrm{a}}$ ed. São Paulo: Editora da Universidade de São Paulo, 2002, p. 131-154.

GARCIA, Miliandre. “Ou vocês mudam ou acabam": teatro e censura na ditadura 
militar (1964-1985). Tese de doutorado em História. Rio de Janeiro, UFRJ, 2008.

GOMES, Dias. O engajamento é uma prática de liberdade. Revista Civilização Brasileira, Caderno Especial, n $^{\circ}$. 2, Rio de Janeiro, Civilização Brasileira, 1968, p. 7-17.

GOULD, Jean. Dentro e fora da Broadway: o teatro moderno americano. Rio de Janeiro: Edições Bloch, 1968.

HOBSBAWM, Eric J. História social do jazz. $2^{\mathrm{a}}$ ed. Rio de Janeiro: Paz e Terra, 1991.

HOLLANDA, Heloísa Buarque de e GONÇALVES, Marcos. Cultura e participação nos anos $60.10^{\mathrm{a}}$ ed. São Paulo: Brasiliense, 1995.

JAMESON, Fredric. Filmar $O$ capital? Crítica Marxista, n. 30, São Paulo, Unesp, 2010, p. 67-74.

KÜHNER, Maria Helena e ROCHA, Helena. Opinião: para ter opinião. Rio de Janeiro: Relume Dumará/Prefeitura, 2001.

LÍVIO, Tito. Teatro Moderno de Lisboa (1961-1965): um marco na história do teatro português. Alfragide: Caminho, 2009.

MICHALSKI, Yan. $O$ teatro sob pressão: uma frente de resistência. Rio de Janeiro: Jorge Zahar, 1985.

MOSTAÇO, Edélcio. Teatro e política: Arena, Oficina e Opinião. São Paulo: Proposta Editorial, 1982.

NAPOLITANO, Marcos. "Seguindo a canção": engajamento político e indústria cultural na MPB (1959-1969). São Paulo: Annablume/Fapesp, 2001.

NEVES, João das. $O$ último carro: antitragédia brasileira. $5^{\mathrm{a}}$ ed. Rio de Janeiro: Grupo Opinião, 1976.
. O último carro. Arte em Revista, $\mathrm{n}$. 6, São Paulo, Kairós, 1981, p. 7-8.

Ciclo de palestras sobre o teatro brasileiro, 5. Rio de Janeiro: Inacen, 1987.

REBELLO, Luiz Francisco. Combate por um teatro de combate. Lisboa: Seara Nova, 1977.

REIS, Daniel Aarão. Ditadura militar, esquerdas e sociedade. Rio de Janeiro: Jorge Zahar Ed., 2000.

SAMUEL, Rafael, MACCOLL, Ewan e COSGROVE, Stuart. Theatres of the left 1880-1935: workers' theatre movements in Britain and America. London: Routledge \& Kegan Paul, 1985.

SANTOS, Graça dos. Teatro possível e impossível durante o Salazarismo. Estudos do Século XX, Coimbra, n. 1, 2001, p. 99-115.

TINHORÃO, José Ramos. Um equívoco de 'Opinião'. In: Música popular: um tema em debate. São Paulo: Ed. 34, 1997, p. 72-87.

TOLEDO, Caio Navarro de. $O$ governo Goulart e o golpe de 64. São Paulo: Brasiliense, 1997.

WERNECK, Maria Helena e BRILHANTE, Maria João (orgs.). Teatro e imagem: estudos de teatro. Rio de Janeiro: 7Letras, 2009.

WILCOX, Frank Blair. Contemporary portuguese theater. Illinois: University of Illinois at Urbana-Champaign, 1971.

\section{Referência discográfica}

Grupo Opinião. CD Show Opinião. PolyGram, 1994. 


\section{Resumo}

Teatro social e teatro engajado são denominações que ganharam corpo em meio a um vivo debate que atravessou o final do século XIX e se consolidou no século XX. Seu ponto de inflexão estava na tessitura das relações entre teatro e política ou mesmo entre teatro e propaganda. Este artigo aborda os sentidos de resistência e contestação político-cultural dos grupos Opinião, do Rio de Janeiro, e Teatro Moderno de Lisboa, levando em consideração os discursos produzidos sobre seus processos coletivos de criação, pesquisa teórica e intervenção social.

Palavras-chave: Grupo Opinião; Teatro Moderno de Lisboa; teatro engajado; arte.
Abstract
Social theater and engaged theater are denominations that took shape in the midst of a hot debate that took place throughout the end of the $19^{\text {th }}$ century and was consolidated in the $20^{\text {th }}$ century. Their novelty rested on the relationship they have established between theater and politics or even between theater and propaganda. This article approaches the meanings of resistance and political-cultural contestation of the groups Opinião and Teatro Moderno de Lisboa while taking into account the discourses produced on their collective processes of creation, theoretical research and social intervention.

Key words: Grupo Opinião; Teatro Moderno de Lisboa; engaged theater; art.

\section{Résumé}

Théâtre social et théâtre engagé ce sont des dénominations qui ont pris corps au sein d'un vif débat qui a traversé la fin du XIX ${ }^{\text {ème }}$ siècle, s'étant consolidé au XX $\mathrm{XX}^{\mathrm{em}}$. Son point d'inflexion se situait dans la trame des relations entre théâtre et politique, voire entre théâtre et propagande. Le présent article aborde les sens de résistance et de contestation politico-culturelle des groupes Opinião et Teatro Moderno de Lisboa, en tenant compte des discours produits sur leurs processus collectifs de création, de recherche théorique et d'intervention sociale.

Mots-clés: Grupo Opinião; Teatro Moderno de Lisboa; théâtre engagé; art. 